\title{
The Impact of Multiple Micronutrient Supplementation on Hemoglobin Concentration in Pregnant and Neonatal Birth Wight
}

\author{
Abdul Faris $^{1 \star}$, Muhammad Tahir Abdullah ${ }^{1}$, Veni Hadju² \\ ${ }^{1}$ Department of Public Health, Universitas Hasanuddin, Makassar, Indonesia; ${ }^{2}$ Department of Nutrition, Universitas Hasanuddin, \\ Makassar, Indonesia
}

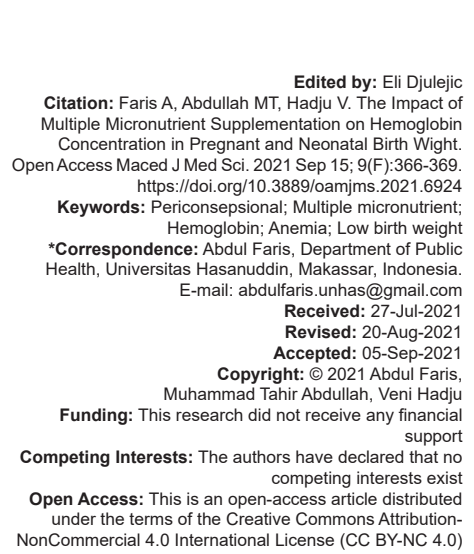

\section{Introduction}

Anemia during pregnancy is a public health problem, especially in developing countries and it is associated with maternal and perinatal adverse outcomes. The World Health Organization (WHO) has defined anemia in pregnancy as the hemoglobin $(\mathrm{Hb})$ concentration of $<11 \mathrm{~g} / \mathrm{dl}$. Anemia is considered of a severe public health significance if its rate of $\geq 40 \%$ and Global data shows that $56 \%$ of pregnant women in low- and middle-income countries have anemia [1]. The prevalence of anemia is highest among pregnant women in sub- Sahara Africa $(57 \%)$, followed by pregnant women in South-East Asia (48\%) and lowest prevalence $(24.1 \%)$ was reported among pregnant women in South America [2].

For Indonesia, according to [3], the proportion of anemia in pregnant women is $48.9 \%$, higher than in 2013 which was $37.1 \%$. Additional data that we can see, the coverage of giving blood-added tablets to pregnant women is $73.2 \%$, but those who get tablets $\geq 90$ items are only $24 \%$. The proportion of anemia in pregnant women above becomes an irony amid the incessant national nutrition improvement program

Every year $>20$ million infants are born with low birth weight (LBW) worldwide. About 3.6 million infants die during the neonatal period. Two-thirds of these deaths occur in southern Asia and sub-Saharan Africa. MMN supplementation in pregnant women may be a promising strategy for reducing adverse pregnancy outcomes through improved maternal nutritional and immune status. The WHO currently recommends iron and folic acid supplementation to reduce the risk of iron deficiency anemia arhong pregnant women. Since many developing countries already have systems in place for the delivery of iron and folic acid supplements, micronutrient supplements could be provided at little additional cost [4], [5].

Based on the problems presented above this paper intends to provide an explanation of the 
importance of nutritional supplementation, especially micronutrients in the periconceptional period of $\mathrm{Hb}$ levels in pregnant women and birth weight of infants.

\section{Methods}

The study was conducted from October to November 2019. The databases used in the literature search were PubMed, ScienceDirect, MEDLINE, and PubMed Central. Multiple Micronutrient Supplementation, Hb, Pregnant, and Neonatal Birth Weight were used as keywords in finding appropriate literatures published from 2010 to 2020 . A total of 14 articles were used in this review. The preparation, categorization, and documentation had done using Mendeley software.

\section{Results}

The results of literature review through the Google search engine with the keywords "preconception nutrition" or "prenatal nutrition or" preconceptional supplementation of MMNs", pregnant women, $\mathrm{Hb}$ levels, and LBW, obtained several research results published in various scientific journals published. The results of tracing the literature are presented in Tables 1 and 2.

\section{MMNs and $\mathrm{Hb}$ levels in pregnant women}

Of the seven studies obtained about the effects of MMNs on $\mathrm{Hb}$ levels in pregnant women, the most research methods were randomized controlled trial (3), followed by prospective cohort study (1), Quasy experimental study (1), exploratory study (1) and Casecontrol study (1). These results are shown in Table 1.

\section{MMNs and LBW}

Of the seven studies obtained on the effects of MMNs on LBW, the most research methods used were meta-analysis (3), systematic review (2), randomized controlled trials (1) and cohort (1). These results are shown in Table 2.

\section{Discussion}

Refer to Planning Guidelines The first 1000 days of life Movement Program that has been compiled since 2013 and has been implemented, then nutrition interventions specific is iron folate supplementation, $\mathrm{Zn}$ supplementation for toddlers, substance fortification iron. If you see specific nutrition interventions in SUN framework is MMN supplementation MMN, and MMN fortification. Until now it seems that there is no signal that the government will take steps replacing added blood tablets TTD which contain $60 \mathrm{mg}$ of elemental iron and $250 \mu \mathrm{g}$ acid folate, with a MMN supplement contains various vitamins and minerals [14]. MMNs contain 15 types of Vitamins and minerals that are most

Table 1: Effects of MMN on $\mathrm{Hb}$ levels and serum ferritin in pregnant women

\begin{tabular}{|c|c|c|c|}
\hline Study & Treatment & $\mathrm{Hb}$ level & Ferritin Serum \\
\hline $\begin{array}{l}\text { Patimah et al. } \\
\text { (2013) [6] }\end{array}$ & $\begin{array}{l}\text { The study was a randomized controlled trial conducted in Maros } \\
\text { Regency. The first group }(n=35) \text { received a MMN supplement daily, } \\
\text { second group }(n=35) \text { received a iron-folic acid tablet daily, respectively } \\
\text { for } 12 \text { consecutive weeks }\end{array}$ & $\begin{array}{l}\text { Mean } \mathrm{Hb} \text { levels increased significantly after the } \\
\text { supplementation of MMNs whereas iron folic acid } \\
\text { supplement did not increase significantly }\end{array}$ & $\begin{array}{l}\text { ferritin serum levels of the two } \\
\text { groups were not significantly } \\
\text { decreased after supplementation } \\
\text { MMN and iron-folic acid }\end{array}$ \\
\hline $\begin{array}{l}\text { Serdula et al. } \\
\text { (2019) [7] }\end{array}$ & $\begin{array}{l}\text { A double-blind randomized controlled trial was conducted in China } 18,775 \\
\text { nulliparous women with a } \mathrm{Hb} \text { concentration }>100 \mathrm{~g} / \mathrm{L} \text { were randomly } \\
\text { assigned to receive daily } \mathrm{FA}(400 \mu \mathrm{g}) \text {; IFA (FA, Fe } 30 \mathrm{mg} \text { ), or MMN (FA, Fe } \\
\text { and } 13 \text { micronutrients) from before } 20 \text { gestational weeks until delivery }\end{array}$ & $\begin{array}{l}\text { Compared to FA alone, prenatal IFA and MMN } \\
\text { provided to women with no or mild anemia did } \\
\text { not affect anemia in women post-partum or } \\
\text { their infants regardless of baseline maternal Hb } \\
\text { concentration at enrollment }\end{array}$ & \\
\hline Sari et al. (2017) [8] & $\begin{array}{l}\text { A Quasi experimental study with randomized control group pre-post test } \\
\text { design } 40 \text { pregnant women with a gestational age of } 20 \pm 1 \text { week were } \\
\text { divided into two groups, the intervention group (MMN supplementation) } \\
\text { and the control group (Fe supplementation) for } 6 \text { weeks }\end{array}$ & $\begin{array}{l}\text { The average increase in } \mathrm{Hb} \text { levels after } \\
\text { MMN supplementation is higher than after } \mathrm{Fe} \\
\text { supplementation. This difference is significant }\end{array}$ & \\
\hline $\begin{array}{l}\text { Wibowo and Irwinda } \\
\text { (2015) [9] }\end{array}$ & $\begin{array}{l}\text { An exploratory study in Jakarta of } 100 \text { pregnant women } \leq 12 \text { weeks } \\
\text { Subjects received milk powder formulations containing MMNs and } \\
\text { protein supplements every month until delivery }\end{array}$ & $\begin{array}{l}\text { Maternal } \mathrm{Hb} \text { level during pregnancy cannot be } \\
\text { maintained or enhanced by MMN and protein } \\
\text { supplementation }\end{array}$ & $\begin{array}{l}\text { Maternal ferritin and iron levels } \\
\text { during pregnancy cannot be } \\
\text { maintained/enhanced by MMN and } \\
\text { protein supplementation }\end{array}$ \\
\hline $\begin{array}{l}\text { Hariyadi et al. } \\
(2015)[10]\end{array}$ & $\begin{array}{l}\text { Casecontrol with a sample of } 36 \text { respondents selected and divided into } \\
\text { two groups; intervention and control }\end{array}$ & $\begin{array}{l}\text { Blood booster tablets and vitamin } \mathrm{C} \\
\text { supplementation show significant results in } \\
\text { increasing } \mathrm{Hb} \text { levels in pregnant women who take } \\
\text { blood-booster tablets }\end{array}$ & \\
\hline $\begin{array}{l}\text { Nguyen et al. (2016) } \\
\text { [11] }\end{array}$ & $\begin{array}{l}\text { A double blind randomized controlled trial in which } 5011 \text { Vietnamese } \\
\text { women were provided with weekly supplements containing either only } \\
2800 \mu \mathrm{g} \text { FA (control group), IFA ( } 60 \mathrm{mg} \text { Fe and } 2800 \mu \mathrm{g} \mathrm{FA} \text { ) or MMN (15 } \\
\text { micronutrients with similar amounts of IFA) }\end{array}$ & $\begin{array}{l}\text { Preconception supplementation with MMN or IFA } \\
\text { resulted in modest increases in maternal and } \\
\text { infant iron stores but did not impact anemia }\end{array}$ & $\begin{array}{l}\text { In intention to treat analyses, } \\
\text { prenatal ferritin was significantly } \\
\text { higher among women receiving } \\
\text { MMN }\end{array}$ \\
\hline $\begin{array}{l}\text { Kang et al. (2017) } \\
\text { [12] }\end{array}$ & $\begin{array}{l}\text { A prospective cohort study in rural Tibet of China. Daily supplementation } \\
\text { with FA and MMN containing a recommended allowance of twenty-three } \\
\text { vitamins and minerals in another county starting } \leq 24 \text { weeks of gestation } \\
\text { and continuing until delivery }\end{array}$ & $\begin{array}{l}\text { Compared with the FA group, prenatal } \\
\text { supplementation with MMN was significantly } \\
\text { associated with reduced odds of anemia in the } \\
\text { third trimester }\end{array}$ & \\
\hline
\end{tabular}


Table 2: Effects of MMN on LBW and other outcomes

\begin{tabular}{|c|c|c|c|}
\hline Study & Treatment & LBW & other results \\
\hline $\begin{array}{l}\text { Kawai et al. (2011) } \\
{[4]}\end{array}$ & $\begin{array}{l}\text { To systematically review randomized controlled trials comparing the } \\
\text { effect of supplementation with rtiultiple micronutrients versus iron } \\
\text { and folic acid on pregnancy outcomes in developing countries }\end{array}$ & $\begin{array}{l}\text { MMN supplementation was more effective than iron } \\
\text { and folie acid supplementation at reducing the risk } \\
\text { of LBW and of small size for gestationai age }\end{array}$ & $\begin{array}{l}\text { Micronutrient supplementation had no } \\
\text { overall effect on perinatal mortality }\end{array}$ \\
\hline $\begin{array}{l}\text { Smith et al. (2017) } \\
\text { [13] }\end{array}$ & $\begin{array}{l}\text { This two-stage meta-analysis of individual patient included data from } \\
17 \text { randomized controlled trials done in } 14 \text { low-income and middle- } \\
\text { income countries, which compared MMN supplements containing } \\
\text { iron-folic acid versus iron-folic acid alone in } 112953 \text { pregnant women }\end{array}$ & $\begin{array}{l}\text { MMN supplements resulted in greater reductions in } \\
\text { low birth weight } \\
\text { Initiation of MMN supplements before } 20 \text { weeks } \\
\text { gestation provided greater reductions in preterm birth }\end{array}$ & $\begin{array}{l}\text { MMN supplements containing iron-folic } \\
\text { acid provided significantly greater } \\
\text { reductions in neonatal mortality for female } \\
\text { neonates, smallfor-gestational-age births, } \\
\text { and 6-month mortality }\end{array}$ \\
\hline $\begin{array}{l}\text { Sumarmi (2017) } \\
{[14]}\end{array}$ & $\begin{array}{l}\text { Randomized double-blind community-based Trial in Probolinggo } \\
\text { East Java revealed that extended MMNs intervention 2-6 months } \\
\text { prior to pregnancy }\end{array}$ & $\begin{array}{l}\text { MMNs intervention 2-6 months prior to pregnancy } \\
\text { provided better effect on birth weight }\end{array}$ & $\begin{array}{l}\text { MMNs intervention provided better effect } \\
\text { on placental weight, maternal endocrine, } \\
\text { and immune response }\end{array}$ \\
\hline $\begin{array}{l}\text { Zerfu and Ayele } \\
\text { (2013) [15] }\end{array}$ & $\begin{array}{l}\text { To systematically review the effect of supplementing various } \\
\text { combinations and types of micronutrients on the course and } \\
\text { outcomes of pregnancy }\end{array}$ & $\begin{array}{l}\text { MMNs supplementation have beneficial effect in } \\
\text { reducing the risk of LBW and small for Gestational } \\
\text { Age births }\end{array}$ & $\begin{array}{l}\text { significant benefit of } \mathrm{MMN} \\
\text { supplementation during pregnancy in } \\
\text { reducing preeclampsia }\end{array}$ \\
\hline $\begin{array}{l}\text { Wang et al. (2013) } \\
\text { [16] }\end{array}$ & $\begin{array}{l}\text { A cohort study to determine the effect of MMN administration on } \\
\text { pregnancy outcomes }\end{array}$ & $\begin{array}{l}\text { MMNs supplementation have beneficial effect in } \\
\text { reducing the risk of LBW and small for Gestational } \\
\text { Age births }\end{array}$ & $\begin{array}{l}\text { MMNs supplementation have beneficial } \\
\text { effect in reducing the risk of stillbirths, and } \\
\text { NTD anomaly }\end{array}$ \\
\hline $\begin{array}{l}\text { Bourassa et al. } \\
\text { (2019) [17] }\end{array}$ & $\begin{array}{l}\text { Two recent reviews, a Cochrane systematic review and meta- } \\
\text { analysis and an individual participant data (IPD) meta-analysis, have } \\
\text { assessed trials that compared the use of MMS with IFA in pregnant } \\
\text { women and were predominantly conducted in LMIC }\end{array}$ & $\begin{array}{l}\text { Recent meta-analyses demonstrate that MMS can } \\
\text { reduce the risks of preterm birth, LBW, and small } \\
\text { for gestational age in comparison with IFA alone }\end{array}$ & \\
\hline
\end{tabular}

LBW: Low birth weight, MMN: Multi Micronutrients, $\mathrm{Hb}$ : Hemoglobin.

important for pregnant women including Vitamin $A$, Vitamin E, Vitamin D, Vitamin B1, Vitamin B2, niacin, Vitamin B6, Vitamin B12, folic acid, Vitamin C, Fe, zinc, copper, selenium, and iodine [19], [20].

\section{MMNs and $\mathrm{Hb}$ levels in pregnant women}

Table 1 shows that most studies support that MMN supplementation increases $\mathrm{Hb}$ levels or prevents pregnant women from anemia [6], [7], [8], [9], [10], [11], [12]. Similarly, the effect of MMN on serum ferritin, one study reported ferritin levels in the MMN group as well as the fe-folic acid group did not experience a significant decrease [6], and one study showed a significant increase in serum ferritin [11]. There is only one study that shows the opposite results, which research using milk powder containing MMNs and proteins given to pregnant women every month from gestational age $\leq 12$ weeks until delivery. The mean maternal $\mathrm{Hb}$ level significantly decreased during the study ( $p<0.001$ ), being the lowest in the second trimester. Ferritin and serum iron levels were decreased at trimester one and two ( $p<0.001)$, also the zinc and vitamin $D$ level declined [9].

\section{MMNs and LBW}

Table 2 shows the effect of MMN supplementation on pregnancy outcomes is better than Fe-folic acid supplementation. This can be seen in the results reported from various studies that have been carried out, which are reduce the incidence of LBW [4], [13], [14], [15], [16], [17], [18], small for gestational age [15], [16], [17], [18], preterm labor [13], [17], [18]. Stillbirths, and neural tube defect anomaly [16].

Critical period to determine healthy pregnancy as well as the quality of the baby's being born is a time of moments conception or so-called conception (periconceptional period). Perception concept consists of periods before conception (preconception), conception stage, implantation, placentation, and embryogenesis or stage organogenesis, as well as specific cellular events which occur during the embryogenesis stage different [14].

Related to micronutrient interventions, Unicef actually did it MMN supplementation program for pregnant women in several regions in Indonesia, among others in West Nusa Tenggara (Central Lombok District), Nusa Tenggara East (Sikka and Belu Regencies), as well as at Central Java (Klaten Regency). This program it's time to expand coverage the area, and the scope of the target not only pregnant women, but it is very important prepared for the intervention program preconception [14].

\section{Conclusion}

Various empirical evidence that has been described in this paper confirms the plausibility that the provision of micronutrient supplementation in the periconceptional period is more important than only given during advanced pregnancy. MMN administration increases $\mathrm{Hb}$ levels in pregnant women and improves pregnancy outcomes.

\section{References}

1. Stephen G, Mgongo M, Hussein Hashim T, Katanga J, StrayPedersen B, Msuya SE. Anaemia in pregnancy: Prevalence, 
risk factors, and adverse perinatal outcomes in Northern Tanzania. Anemia. 2018;2018:e1846280. https://doi. org/10.1155/2018/1846280

PMid:29854446

2. Adam I, Ibrahim Y, Elhardello O. Prevalence, types and determinants of anemia among pregnant women in Sudan: A systematic review and meta-analysis. BMC Hematol. 2018;18:31. https://doi.org/10.1186/s12878-018-0124-1 PMid:30455961

3. Basic Health Research. Main Results Basic Health Research 2018. Jakarta: Ministry of Health; 2018.

4. Kawai K, Spiegelman D, Shankar AH, Fawzi WW. Maternal multiple micronutrient supplementation and pregnancy outcomes in developing countries: Meta-analysis and metaregression. Bull World Health Organ. 2011;89(6):402-11. https:// doi.org/10.2471/blt.10.083758

PMid:21673856

5. Zeng L, Yan H, Cheng Y, Dang S, Dibley MJ. Adherence and costs of micronutrient supplementation in pregnancy in a double-blind, randomized, controlled trial in rural western China. Food Nutr Bull. 2009;30(4):S480-7. https://doi. org/10.1177/15648265090304s402

PMid:20120789

6. Patimah S, As'ad S, Jusoff K, Hadju V, Thaha A, Bahar B. The influence of multiple micronutrient supplementations on hemoglobin and serum ferritin levels of pregnant women. World J Med Sci. 2013;8(3):177-85.

7. Serdula MK, Zhou Y, Li H, Liu JM, Mei Z. Prenatal iron containing supplements provided to Chinese women with no or mild anemia had no effect on hemoglobin concentration in post-partum women or their infants at 6 and 12 months of age. Eur J Clin Nutr. 2019;73(11):1473-9. https://doi.org/10.1038/ s41430-018-0365-x

PMid:30446762

8. Sari RP, Pramono N, Wahyuni S, Sofro MA, Widyawati MN. Effect of multi micronutrient supplementation on hemoglobin levels in pregnant women with anemia. Belitung Nurs J. 2017;3(6):677-85. https://doi.org/10.33546/bnj.291

9. Wibowo N, Irwinda R. The effect of multi-micronutrient and protein supplementation on iron and micronutrients status in pregnant women. Med J Indonesia. 2015;24(3):168-75. https:// doi.org/10.13181/mji.v24i3.1209

10. Hariyadi D, Farida S, Marlenywati M. Pengaruh Vitamin C terhadap peningkatan hemoglobin pada wanita hamil di Kecamatan Pontianak Timur. J Vokasi Kesehatan. 2015;1(5):146-53.

11. Nguyen $\mathrm{PH}$, Young $\mathrm{M}$, Gonzalez-Casanova I, Pham $\mathrm{HQ}$, Nguyen $\mathrm{H}$, Truong TV, et al. Impact of preconception micronutrient supplementation on anemia and iron status during pregnancy and postpartum: A randomized controlled trial in rural vietnam. PLoS One. 2016;11(12):e0167416. https://doi. org/10.1371/journal.pone.0167416

\section{PMid:27918586}

12. Kang Y, Dang S, Zeng L, Wang D, Li Q, Wang J, et al. Multimicronutrient supplementation during pregnancy for prevention of maternal anaemia and adverse birth outcomes in a highaltitude area: A prospective cohort study in rural Tibet of China. Br J Nutr. 2017;118(6):431-40. https://doi.org/10.1017/ s000711451700229x

PMid:28980891

13. Smith ER, Shankar AH, Wu LS, Aboud S, Adu-Afarwuah S, Ali $\mathrm{H}$, et al. Modifiers of the effect of maternal multiple micronutrient supplementation on stillbirth, birth outcomes, and infant mortality: A meta-analysis of individual patient data from 17 randomised trials in low-income and middle-income countries. Lancet Global Health. 2017;5(11):e1090-100. https:// doi.org/10.1016/s2214-109x(17)30371-6

PMid:29025632

14. Sumarmi SM. A review on multi micronutrients intervention during the first 1000 days of live. J Nutr Food Res. 2017;40:1728. https://doi.org/10.22435/pgm.v40i1.6374.17-28

15. Zerfu TA, Ayele HT. Micronutrients and pregnancy; effect of supplementation on pregnancy and pregnancy outcomes: A systematic review. Nutr J. 2013;12(1):20. https://doi. org/10.1186/1475-2891-12-20

16. Wang YF, Pei LJ, Song XM, Chen G, Zheng XY. Impact of periconceptional multi-micronutrient supplementation on gestation: A population-based study. Biomed Environ Sci. 2013;26(1):23-31.

PMid:23294612

17. Bourassa MW, Osendarp SJ, Adu-Afarwuah S, Ahmed S, Ajello C, Bergeron G, et al. Review of the evidence regarding the use of antenatal multiple micronutrient supplementation in low-and middle-income countries. Ann $N$ Y Acad Sci. 2019;1444(1):6-21. https://doi.org/10.1111/nyas.14121 PMid:31134643

18. Fall $\mathrm{CH}$, Fisher DJ, Osmond C, Margetts BM, Materna Micronutrient Supplementation Study Group. Multiple micronutrient supplementation during pregnancy in low-income countries: A meta-analysis of effects on birth size and length of gestation. Food Nutr Bull. 2009;30(4):S533-46. https://doi. org/10.1177/15648265090304s408 PMid:20120795

19. Gernand AD, Schulze KJ, Stewart CP, West KP, Christian P. Micronutrient deficiencies in pregnancy worldwide: Health effects and prevention. Nat Rev Endocrinol. 2016;12(5):274-89. https://doi.org/10.1038/nrendo.2016.37

20. Oh C, Keats EC, Bhutta ZA. Vitamin and minera supplementation during pregnancy on maternal, birth, child health and development outcomes in low-and middle-income countries: A systematic review and meta-analysis. Nutrients. 2020;12(2):491. https://doi.org/10.3390/nu12020491

PMid:27032981 